\section{ON THE COLLECTION OF A PENINSULAR ENDEMIC, BARLERIA STOCKSII (ACANTHACEAE), AFTER A CENTURY}

\section{R. Vijaya Sankar ${ }^{1}, \mathrm{~K}$. Ravikumar and N.M. Ganesh Babu}

Foundation for Revitalisation of Local Health Traditions (FRLHT), 74/2, Jarakabande Kaval, Post Attur, Yelahanka, Bangalore, Karnataka 560064, India

Email: ${ }^{1}$ r.vijasankar@frlht.org.in

web supplement

\section{Materials examined}

Andhra Pradesh: Maredumilli, Kakinada, East Godavari dist. 2001, 600-1000m., K.N. Reddy 79607 (FRLHT).

Barleria stocksii T. Anders. in J. Linn. Soc. ix, 493, 1867; C.B. Clarke in Hook.f., Fl. Brit. India 4: 489, 1884; Gamble, Fl. Pres. Madras 2: 1060 (743), 1924. (ACANTHACEAE).

Unarmed undershrubs, up to $75 \mathrm{~cm}$ high; stems sparsely hirsute. Leaves decussate, elliptic-ovate, 3-5 x 1-2cm, subcoriaceous, glabrescent, with minute whitish dots, obtuse at base, subacute at apex, entire or rarely denticulate and hispid-ciliate along margin, sessile; cystoliths in lamina linear, irregularly scattered, blackish when dry. Flowers solitary, in upper axils, ca $5 \mathrm{~cm}$ across; bracteoles narrowly oblong-spathulate, up to $2.5 \mathrm{x}$ $0.4 \mathrm{~cm}$, slightly longer than calyx, obsolute-acute at apex, long hispid-climate along margin; calyx-lobes four, outer lobes linearlanceolate, $1.8-2.2 \times 0.2-0.4 \mathrm{~cm}$, subacuminate at apex, hispidciliate along margin, one of the outer lobes bifid at apex, inner pair linear, ca $1.2 \times 0.2 \mathrm{~cm}$, acuminate at apex, hispid-ciliate along margin; corolla-tube cylindrical below, funnel-shaped above, lobes broadly obovate-emarginate, pinkish. Capsules obovoid with a beaked apex, narrowed at base. Seeds discoid, densely wolly (Image $1^{\mathrm{w}}$ ).

This species is endemic to the Deccan Peninsula (Andhra Pradesh \& Karnataka). The type locality is Bababudan hills (presently in Chickmagalur district) of erstwhile Mysore in Karnataka and the type specimens were collected by Stocks and described by Anderson (1867). The second collection was made by Gamble from Goontoor hills (Gooty) of Anantapur in Andhra Pradesh between 1883-1889 (JSG 20938). Sharma (1984), Ahmedullah and Nayar (1987), Nayar (1996), and Ali Moulali (1997) quoted only the earlier collections and localities of Stocks and Gamble in their publications. Subsequent explorations in the two states did not yield further collection of this rare species, for over a century, until K.N. Reddy collected it from Maredumilli, East Godavari district of Andhra Pradesh.

This species is similar to $B$. montana, but can easily be distinguished by its sessile leaves with obtuse base and densely hispid-ciliate, narrow calyx-lobes.

It is observed in the presented locality, Maredumilli R.F., as rare and only very few plants have been noticed in shady moist places of semi-evergreen forest above $600 \mathrm{~m}$ altitude. Focused explorations are needed in the adjacent forests of similar habitat in order to ascertain the population status that would help in taking up conservation action.

\section{REFERENCES}

Ahmedullah, M. and M.P. Nayar (1987). Endemic Plants of the Indian Region. Botanical Survey of India, Calcutta, 147pp.

Ali moulali, D. (1997). Acanthaceae, 465-921pp. In: Pullaiah, T. and D. Ali Moulali. Flora of Andhra Pradesh (India), Vol. 2. Scientific Publishers, Jodhpur.

Anderson, T. (1867). An enumeration of the Indian species of Acanthaceae. Journal of the Linnaean Society 9: 493pp.

Karthikeyan, S. (2000). A statistical analysis of flowering plants of India, Part-II, 201-217pp. In: Singh, N.P., D.K. Singh, P.K. Hajra \& B.D. Sharma (eds.). Flora of India - Introductory Volume. Botanical Survey of India, Calcutta.

Nayar, M.P. (1996). Hot Spots of Endemic plants of India, Nepal and Bhutan. Tropical Botanical Garden and Research Institute, Palode, Thiruvananthapuram, 204pp.

Sharma, B.D., N.P. Singh, R.S. Raghavan and U.R. Deshpande (1984). Flora of Karnataka - Analysis. Botanical Survey of India, Calcutta, 203pp.

\section{ACKNOWLEDGEMENTS}

The authors are thankful to Sri. Darshan Shankar, Director and Sri. D.K. Ved, Additional Director, FRLHT, Bangalore for facilities and support; Dr. P. Lakshminarashimhan, Scientist ' $C$ ' and IBLO, Kew, London for providing copy of the protologue; Dr. M. Sanjappa, Director, Botanical Survey of India, Calcutta and Dr. H.J. Chowdhery, Joint Director, Central National Herbarium, Howrah for providing cibachrome and Dr. J.L. Ellis (Retd. Scientist, BSI), Bangalore for critical comments on the manuscript.

${ }^{\text {w }}$ See Image 1 in the web supplement at www.zoosprint.org 